This item was submitted to Loughborough's Institutional Repository (https://dspace.lboro.ac.uk/) by the author and is made available under the following Creative Commons Licence conditions.

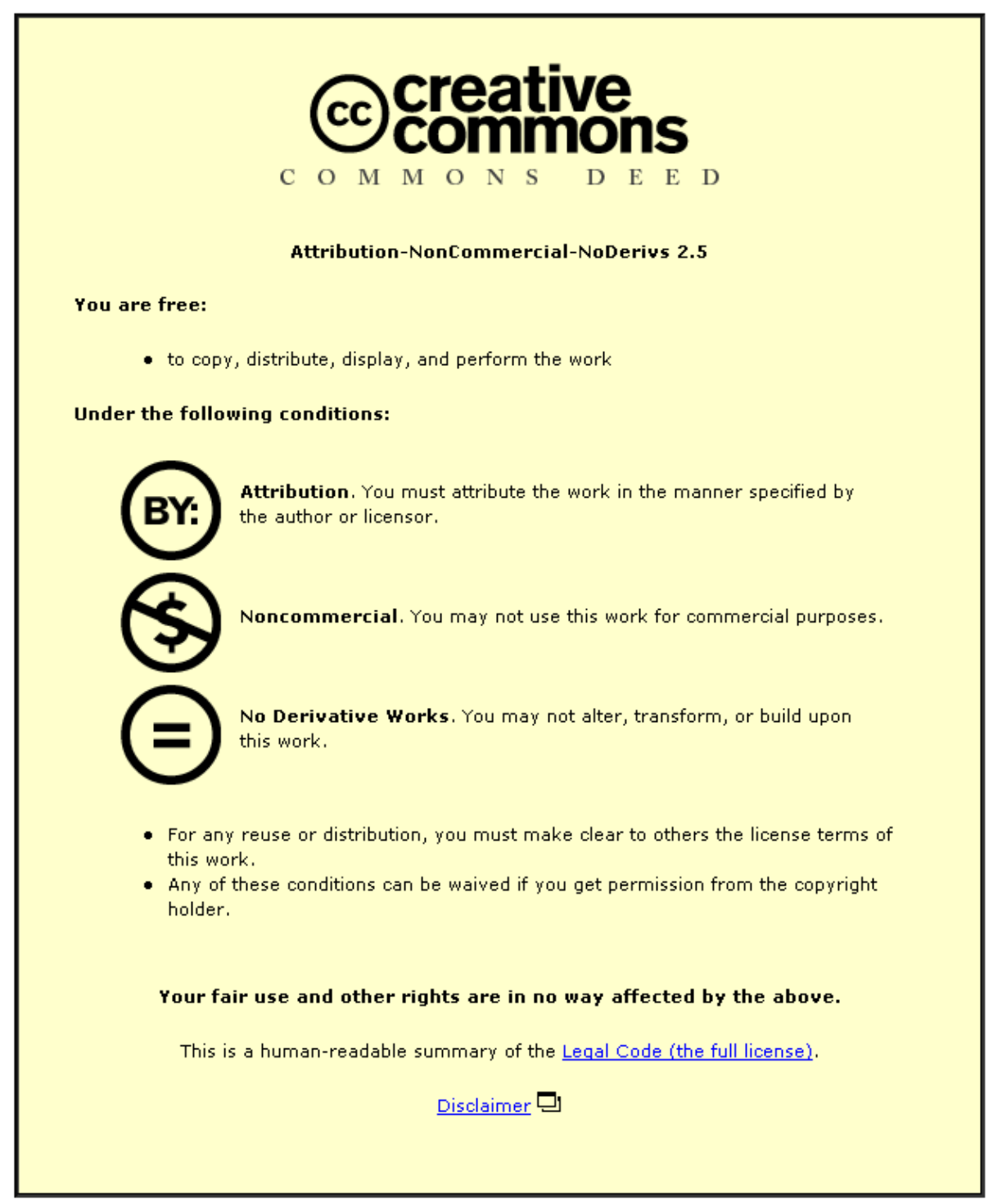

For the full text of this licence, please go to: http://creativecommons.org/licenses/by-nc-nd/2.5/ 


\title{
INJURY SEVERITY ANALYSIS OF ACCIDENTS INVOLVING YOUNG MALE DRIVERS IN GREAT BRITAIN
}

\begin{abstract}
Young male drivers are over-represented in traffic accidents, being involved in 14\% of fatal accidents during the period 1991 to 2003 whilst holding only $8 \%$ of all driving licences in the UK. In this study, a subset of the UK national road accident data from the period 1991 to 2003 has been analysed. The primary aim is to achieve value for money and effective progress towards the national and London road safety targets by aiding understanding into which road safety measures will reduce the severity of accidents involving young male drivers.
\end{abstract}

Ordered probit models have been used to identify specific accident characteristics that increase the likelihood of one of three categorical outcomes of accident severity: slight, serious or fatal. Characteristics found to lead to a higher likelihood of serious and fatal injuries are generally similar across Great Britain and London but are different from those predicted to lead to a higher likelihood of slight injuries. Those characteristics predicted to lead to serious and fatal injuries include driving in darkness, between Friday and Sunday, on roads with a speed limit of $60 \mathrm{mph}$, on single carriageways, overtaking, skidding, hitting an object off the carriageway and when passing the site of a previous accident. Characteristics predicted to lead to slight injuries include driving in daylight, between Monday and Thursday, on roads with a speed limit of $30 \mathrm{mph}$ or less, at a roundabout, waiting to move and when an animal is on the carriageway. These results aid the selection of policy options that have most scope to reduce the severity of accidents involving young male drivers.

Keywords: Young male drivers, Severity of accidents, Ordered probit models, Safety targets, and Safety policy 


\section{INTRODUCTION}

In 2000, the UK government set up a new national road safety strategy and outcome-based road safety targets in terms of reductions by 2010. This includes the reduction of number of people killed or seriously injured (KSI) by $40 \%$, the reduction of number of children KSI by $50 \%$, and the reduction of number slightly injured per unit of vehicle distance by $10 \%$ in relation to the 1994 1998 average. In addition, London's Road Safety Plan was created by Transport for London (TfL) in 2001, and this extended the national targets to specifically cover the number of pedestrians, pedal cyclists and powered two-wheeler riders who are KSI in London by 2010.

In order to achieve the national and London targets, considerable developments need to be made across all aspects of the road system such as: (a) roads, which are generally the responsibility of the government but could also be the responsibility of other parties e.g. land developers, (b) vehicles, which are both the manufacturer's responsibility and the responsibility of the individual/organisation who owns it and (c) users, who are generally responsible for themselves and who may be travelling for various reasons such as personal choice or out of necessity due to work.

This study will concentrate upon selected users of the road system - male car drivers of the age 17 to 25 inclusive (henceforth termed "young male drivers") - as this group is over-represented in accidents (Moller, 2004, Clarke et al., 2005, Clarke et al., 2006). According to the STATS19 (the UK traffic accident reporting system), 54,516 accidents occurred on Great Britain's roads in 2003 that resulted in at least one individual being KSI. Of these, 6,291 (12\%) involved young male drivers. In 2003, young male drivers held only $7 \%$ of all driving licences and were therefore overrepresented in KSI accidents.

Mathijssen (2005) finds that young males have a relatively high accident risk compared to the rest of the population e.g. whilst forming less than $5 \%$ of the Dutch population, males aged 18-24 formed nearly $25 \%$ of all alcohol intoxicated drivers who were involved in serious injury crashes. Vaez and Laflamme (2005) examine the socio-economic differences (age, gender, class of origin and educational attainment) of Swedish youth (aged 16-30) involved in accidents. They find that there are significant risks among males, persons aged 18-19, those from households classified as "workers" and "others" (e.g. long term unemployed and those on sick leave) as opposed to "salaried employees" or "self-employed", and those with low educational attainment. Ward et al. (2005) find that young male drivers aged 17-20 are up to seven times more likely to die in night-time road accidents than older motorists and up to 17 times more likely to be involved in a fatal accident 
between the hours of 0200 and 0500 , while female drivers in the same age group are two to three times more likely to be killed than older women, regardless of the time of day. One of the most revealing points to arise from this study is how many young males like to test themselves and their cars to the limit and then joke about it afterwards when things go wrong; little concept of risk is apparent, yet the data in the study indicates that the risk is high for this group. Ulleberg (2002), however, concludes that not all young drivers should be treated in the same way with respect to road safety policy. The study identifies six subtypes of young drivers (aged 18-23), identifying two as "high risk" groups in traffic. The first consists of mostly men, characterised by low levels of altruism and anxiety and high levels of sensation seeking, irresponsibility and driving related aggression; the second reported high sensation seeking, aggression, anxiety and driving anger.

Progress towards the national 2010 casualty reduction targets has been analysed in various studies. Broughton and Buckle (2005) found that before 1994, fatality and KSI rates tended to fall in parallel, but since then the fatality rate has fallen more slowly than the KSI rate. This rise in the severity proportion between 1994 and 2003 has risen faster for car occupants than for other road user groups. Broughton and Buckle (2005) go on to state that declining driving standards may have contributed to the increased severity proportion for car occupants, indicating factors such as loss of control, careless/thoughtless/reckless behaviour and aggressive driving. However, the analysis by age cohorts was not conducted for car occupants.

A number of studies used ordered probit models to examine the likelihood of various severity levels sustained under different accident scenarios (e.g. O'Donnell and Connor, 1996; Duncan et al., 1998, Kockelman and Kweon, 2002; and Quddus et al., 2002). It is therefore the purpose of this study to take the lines of research reviewed above further by examining a large subset of British accident data (between 1991 and 2003) and identifying what types of characteristics increase the likelihood of various accident severity levels for accidents involving a specific age group using ordered probit models. This study is the first of its kind to incorporate accident data for the whole of Great Britain and could aid future research associated with young male drivers by identifying different courses of action aimed at reducing the likelihood of accidents that lead to fatalities, serious injuries and slight injuries. Therefore, the primary objectives of this study are: (i) to examine the factors that affect the injury severity of accidents involving young male drivers using ordered probit models, in both London and Great Britain as a whole and to investigate any differences, (ii) to draw conclusions by way of making recommendations to aid London and Great Britain as a whole to improve their records on young male drivers by using appropriate road safety measures. Note that this study will 
consider both those young male drivers who are themselves killed or injured and those accidents involving young male drivers who kill or injure others.

The rest of the paper is organised as follows. A brief discussion on the sources of data and the statistical models used to achieve the study objectives are described in the next section. This is followed by the presentation of the results obtained from the models for both London and Great Britain as a whole. This section also describes some key characteristics most likely to lead injuries from accidents involving young male drivers. The paper ends with a conclusion and avenues for further research.

\section{DATA SOURCES AND STATISTICAL MODELS}

STATS19 National Road Accident data for Great Britain was obtained for the period 1991 to 2003. For every accident reported, data are recorded on the accident, the casualties and the vehicles involved. A large subset of accidents involving young male drivers was extracted from this dataset and used in the analysis. The variable of interest (i.e. dependent variable) is the severity of injury due to an accident involving a young male driver. This is categorised fatal, serious or slight and accounts for $2 \%, 15 \%$ and $83 \%$ of all accidents nationally and $1 \%, 15 \%, 84 \%$ in London, respectively over the period 1991 to 2003. The STATS19 data suggests that the proportion of accidents that involve young male drivers has fallen over the period 1991 to 2003 for both Great Britain as a whole and for London only.

Every observation contained within the dataset represents one accident that involves a young male driver. With the severity of injury caused by the accident, details on factors (independent variables) such as the road, the driver and the environment are also available. Of the 49 independent variables available in the dataset, 21 were hypothesised to have a potential relationship with severity level (includes an additional variable referring to location for the Great Britain dataset only). These variables have been coded for analysis; the coding system is presented in Table 1.

\section{Table 1 is about here}

An ordered probit model is used to examine factors that affect the probability of sustaining one of three injury severities for all accidents involving young male drivers (i.e. the model assumes that an accident has occurred). This model is briefly presented below. 
Consider the case where the dependent variable $\mathrm{Y}$ takes the value 1,2 or 3. Then the unobserved index function $\mathrm{Y}^{*}$ is defined as:

$$
\mathrm{Y}^{*}=\boldsymbol{\beta} \mathbf{X}+\varepsilon
$$

where $\mathrm{Y}^{*}$ is a latent and continuous measure of injury severity faced by an individual involved in an accident, $\mathbf{X}$ is a vector of explanatory variables describing the driver, vehicle, and accident, $\boldsymbol{\beta}$ is a vector of parameters to be estimated, and $\varepsilon$ is a random error term (assumed to follow a standard normal distribution). Assume:

$$
\begin{array}{ll}
\mathrm{Y}=1 \text { if } \mathrm{Y}^{*}<\mathrm{k} 1 & \text { Slight injury } \\
\mathrm{Y}=2 \text { if } \mathrm{k} 1 \leq \mathrm{Y}^{*}<\mathrm{k} 2 & \text { Serious injury } \\
\mathrm{Y}=3 \text { if } \mathrm{k} 2 \leq \mathrm{Y}^{*} & \text { Fatal injury }
\end{array}
$$

where $\mathrm{k} 1$ and $\mathrm{k} 2$ are thresholds to be estimated, and $\mathrm{k} 1<\mathrm{k} 2$. This assumes that if the risk of injury is high then it is reasonable to expect that this will actually be translated into a high level of observed injury. The parameters of the ordered probit model, k1, $\mathrm{k} 2$ and $\beta$, will be measured via maximum likelihood.

Injury severity probabilities for accidents involving young male drivers are also predicted using the estimated ordered probit models as suggested by O'Donnell and Connor (1996), Duncan et al. (1998), and Quddus et al. (2002).

\section{MODEL ESTIMATION RESULTS}

The parameters of the ordered probit models for Great Britain as a whole and London only were estimated by the method of maximum likelihood. Table 2 present the estimation results. In order to determine which characteristics amongst the independent variables are most likely to lead to each of the three severity levels, the probability of each outcome of the dependent variable (i.e. slight, serious or fatal injury) is estimated based upon changes in each of the independent variables in turn, all other things being equal (see Tables 3 and 4). For ease of comparison, a reference case has been constructed while calculating the change in predicted probability for each outcome of the dependent variable. The reference case is an observation in which all dummy variables are set equal to zero and the variable time trend is set equal to 1 (i.e. 1991). 
Creating such a reference case allows us to show how different accident scenarios vary from the reference case by setting each variable in turn to each of its possible coded values, whilst setting all other variables equal to zero and the time trend equal to 1 (1991), i.e. it shows how changes in one independent variable, ceteris paribus, affect the severity level. Note that when percentages are stated in the text below, e.g. $\alpha \% / \delta \%$, the first percentage $(\alpha \%)$ applies to Great Britain as a whole whilst the second $(\delta \%)$ refers to London only.

\section{Table 2 is about here}

Table 2 shows that the time trend variable is statistically significant with a negative sign. This indicates that something that has changed over the study period has lead to a downward trend in injury severity. Therefore, it is suggested that, ceteris paribus, some other unmeasured factor is influencing the relative severity of accidents involving young male drivers. From Table 3, a fatality is $45 \%$ less likely in 2003 in Great Britain than it was in the reference case (1991) and 38\% less likely in London (see Table 4), serious injuries are 26\%/22\% less likely than in the reference case, whilst slight injuries are $9 \% / 5 \%$ more likely than in the reference case. As the model is intended to capture factors that affect the severity of injuries, the changes in probabilities shown in the time trend are assumed to be caused by some other exogenous factors. Noland and Quddus (2003) analysed the impact of improvements in medical treatment and technology and found that medical technology improvements are associated with reductions in traffic-related fatalities over time. This therefore could be one source of the time trend effect shown.

When considering time of day effects, it can be seen that more severe injuries occur earlier in the morning, with less severe injuries during the day. Overall, accidents occurring between 0000-0659 are $23 \% / 20 \%$ more likely to result in a fatality than the reference case (1900-2359), whilst all other time periods are less likely to result in a fatal accident than the reference case. A reason for this could be that alcohol use is likely to be most prevalent at this time of day. The model includes a variable, breath test, indicating a proxy measure for alcohol consumption. The reference case for this variable is "others" representing the cases where the driver either did not request for the breath test or was not present at the scene of the accident. The results of the model for this variable do not confirm the hypothesis that a positive breath test leads to a higher probability of a fatal accident; in fact the results show that both the positive and negative tests (compared with the "others" category) are associated with high injury severity. The differential coefficient for the negative breath test is higher than that of the positive breath test indicating that the negative breath test is more likely to be 
connected to a fatal accident. However, as the young male driver may not be the person that the breath test is related to, it is not possible to ascertain the full effects of young male drivers' alcohol consumption on injury severity probabilities via this variable. In addition to this, the variables day of the week and time of the day might capture some of the effects of alcohol consumption.

\section{Table 3 is about here}

Looking at day of the week effects, it can be seen that relative to the reference case (Monday) less severe accidents are predicted on Tuesdays and Wednesdays (and Thursdays in London), but more severe accidents are predicted on Thursdays (excluding in London), Fridays, Saturdays and Sundays, e.g. a fatality is $14 \% / 19 \%$ more likely on a Saturday. This is logical as young people tend to go out more towards the end of the week, especially the weekend, and again this result is assumed to have some connection to alcohol consumption at this time. The high result for Sunday is assumed to be caused by the large amount of young males still out in the early hours of Sunday morning driving home after a Saturday evening. A possible policy recommendation from this finding is that a curfew needs to be imposed on young male drivers to prevent them driving between the hours of 0000-0659 on Fridays to Sundays. This would entail enforcement issues, would be viewed as a very strict rule and could be discriminatory if only applied to males.

The variable light conditions allows us to consider the effect of the level of light. Tables 3 and 4 show that more severe injuries are predicted during darkness, with fatalities $30 \% / 23 \%$ more likely and serious injuries $13 \% / 11 \%$ more likely than in the reference case (daylight). This result concurs with the results of various studies, including Ward et al. (2005) and Clarke et al.(2006). Reasons for this result may include higher levels of tiredness and alcohol consumption and the associated slower reactions and reduced hazard awareness, but also factors such as the different set of people that use the road at night and their reasons for doing so e.g. driving for social purposes and driving for pleasure, both of which younger drivers do more than other groups of drivers (Ward et al., 2005).

\section{Table 4 is about here}

Seasonal effects, as captured by the variable month of the year, whilst not statistically significant, show that January and May (and April and August for Great Britain as a whole) tend to be the months where the more severe accidents will occur. Although the changing of the clocks is sometimes argued to have an effect on road safety, this is unlikely to be causing the effect here as 
the clocks move forward one hour at the end of March, potentially making it darker in the morning and lighter in the evening, and move backward one hour at the end of October, potentially making it lighter in the morning and darker in the evening. Therefore, according to the results shown above for variable month of the year, the month of April may be expected to have more severe injuries in the darker mornings and the month of November to have more severe injuries in the darker evenings. This however is not supported by the results.

Weather conditions also have an effect on the predicted severity of injury; however the effect is very different for Great Britain as a whole and for London only. For Great Britain as a whole, the weather condition most likely to lead to the most severe injuries is fine no high winds, whereas in London it is fine weather with high winds. Overall, for Great Britain any weather condition different from fine no high winds is generally predicted to increase the likelihood of slight injuries and reduce the likelihood of serious and fatal injuries. In London however, the pattern is generally reversed. It is possible then that the less frequent occurrence of weather of types other than fine no high winds means that individuals in London are less experienced at driving in them and hence are more likely to be involved in serious accidents when they do occur.

The condition of the road surface also has an effect on predicted injury severity. Compared to the reference case (dry), oil or diesel (and wet or damp in London) is predicted to lead to more severe injuries, with oil or diesel resulting in an $8 \% / 91 \%$ higher likelihood of a fatality. It appears that perhaps more obvious hazards such as snow, frost or ice, floods or mud cause the driver to make compensatory measures, such as slowing down, whereas factors such as oil or diesel (which may only be an isolated spill so that the driver has no warning of it) or water (where if it has been raining, the driver becomes accustomed to the rain and forgets that the surface will be affected) may not cause the driver to compensate. This is also supported by the fact that any road condition other than the reference case (dry) is generally likely to increase the likelihood of slight injuries and decrease the likelihood of serious or fatal injuries.

The variable skidding or overturning shows that if a volatile movement occurs, then a more severe injury is predicted, i.e. a fatality is $17 \% / 80 \%$ more likely than in the reference case (no volatile movement). This is logical and is linked to the variable damage. The results of this variable for London show that if damage to the vehicle is caused then a more severe injury is predicted, i.e. a fatality is $5 \%$ more likely than in the reference case (no damage). The results for Great Britain show the reverse, which is surprising. Also, the variable hit object off carriageway shows that hitting an 
object off the carriageway increases the chance of a fatality by $32 \% / 83 \%$ compared to the reference case (hit nothing).

The results of the variable carriageway hazard show that compared to the reference case (no carriageway hazards) a previous accident on the road is predicted to lead to more severe injuries, with a fatality $50 \% / 48 \%$ more likely. This concurs with the results of various studies that show that "rubbernecking", whereby drivers passing a previous accident slow down to watch, is a real problem. Objects on the road and animals on the road are predicted to lead to less severe injuries, possibly because it causes the driver to slow down and increase his concentration.

The variable speed limit shows some interesting results. The highest speed limit, 70mph, does not lead to the most severe accidents; however, this may be because $70 \mathrm{mph}$ is only the speed limit on motorways and dual carriageways. The variable road category shows that motorways are relatively safe, whilst the variable road type shows that a dual carriageway is safer than a single carriageway this is discussed further below. The speed limit associated with the most severe injuries is $60 \mathrm{mph}$ (which legally applies to single carriageways), where a fatality is $81 \% / 62 \%$ more likely than in the reference case $(\leq 30 \mathrm{mph})$.

The results associated with the variable road category show that for Great Britain, A roads are predicted to lead to the most severe injuries, whereas in London B roads and C roads are predicted to lead to more severe injuries. For both Great Britain and London, A(M) roads, motorways and unclassified roads are predicted to lead to less severe injuries. The difference in relative safety of road type between Great Britain and London may be due to the higher volumes of traffic on London A roads and the associated slower speeds relative to A roads in Great Britain as a whole.

The results show that for the variable vehicle manoeuvre overtaking (and being parked in London) is the manoeuvre that is predicted to lead to more severe injuries. Overall, overtaking is associated with a $24 \% / 15 \%$ higher likelihood of a fatality than the reference case (going ahead), suggesting that young male drivers are relatively poor at ascertaining safe overtaking distances and speeds of oncoming traffic.

The variables vehicle location on the road, road type and junction detail, all suggest that junctions are not major causes of more severe injuries. For variable vehicle location on the road, being on the main road is the scenario most likely to lead to a fatality, as opposed to leaving the main road, 
entering the main road or being on a minor road. For variable road type, the results show that being on a single carriageway is most likely to lead to a fatality rather than roundabouts, one-way streets or dual carriageways. For variable junction detail, not being at a junction or within $20 \mathrm{~m}$ of one is associated with the most severe injuries.

For Great Britain as a whole, towing something like a caravan or trailer is predicted to lead to more severe injuries (a fatality is $8 \%$ more likely than the reference case (no tow or articulation)) whereas in London it is not (fatality is $11 \%$ less likely). This discrepancy could be due to the fact that only a very small minority of young male drivers actually tow anything and articulation is not an option as the data only includes car drivers. Again, the results could be related to the level of traffic on the roads; in London, where towing is less likely to result in a fatality, traffic flows are relatively higher and so speeds will also tend to be lower.

The variable driver age suggests that for young male drivers in Great Britain, it is those in the age group 20-22 that are most likely to be involved in accidents resulting in more severe injuries and for London it is the age groups $17-19$ and $20-22$, e.g. those aged $20-22$ are $1 \% / 8 \%$ more likely to be involved in a fatal accident than the reference case (23-25). This finding is consistent with the finding of Clarke et al. (2006).

Finally, the variable regions shows, for the Great Britain dataset only, the effect of accident location on severity level. Accidents occurring in Scotland and the West Midlands are predicted to be associated with more severe injuries, e.g. an accident is $34 \%$ more likely to be fatal if it occurs in Scotland than if it occurs in the reference case (London).

Reasons suggested for the over-representation of young male drivers in accidents, as presented in the introduction section, include the higher likelihood of driving whilst under the influence of alcohol and the overall more risk taking and less law abiding nature of young males e.g. speeding. Factors such as over-confidence, peer pressure, desire to show off, and higher likelihood of driving at night and with multiple passengers are also considered possible causes of the over-representation of young male drivers in car accidents. Whilst not all of these factors are captured by the STATS19 dataset, it has been possible to summarise the following from the ordered probit modelling for Great Britain as a whole and for London only. The key characteristics predicted to increase the probability of fatal, serious and slight injuries are shown in Table 5. 


\section{Table 5 is about here}

According to Golias and Karlaftis (2002) young male drivers tend to fall into the category of "risk takers". Then, as maintained by Ulleberg (2002), if young male drivers' involvement in accidents is to be reduced, it is necessary to force those young males that do not already drive safely to do so because they do not respond well to measures designed to encourage safer driving e.g. safety campaigns. This is an idea corroborated by Tay (2005), who found that enforcement and publicity campaigns produce different results.

It should be noted that the results obtained in this study only refer to the user component of the basic road system, specifically young male drivers; the other two components - roads and vehicles must also be considered when formulating and implementing road safety policy.

\section{CONCLUSIONS}

This paper investigated the factors affecting the severity of accidents involving young male car drivers. The results demonstrated that young male drivers are over-represented in car accidents relative to their level of exposure as measured by their driver license holding level. Young male drivers were more over-represented in Great Britain as a whole than for London, although it could be argued that exposure levels may be lower in London due to more comprehensive public transport and schemes such as the congestion charge which was implemented in February 2003. The significant factors affecting the severity of accidents involving young male drivers are driving in darkness, trips during early morning and towards the end of the week (Friday and Saturday), on the main roads, during overtaking maneouvers, and on the single carriageway of speed limit $60 \mathrm{mph}$. Based on these findings, a number of policies were recommended to reduce the severity of accidents involving young male drivers.

STATS19 data has formed the basis of this study. Whilst the STATS19 form does capture a lot of useful information, it does not capture other factors that would be very useful in understanding the nature of accidents involving young male drivers e.g. number of passengers, mobile phone usage, whether the driver was speeding and years of driving experience. Since 2005, however, police officers completing STATS19 forms have also been required to note the accident's "precipitating factor" (a choice of 1 out of 15 critical failures or manoeuvres that led to the accident) and its "contributory factors" (a choice of up to 4 out of 54 factors that contributed to the critical failure or manoeuvre). For each, the factors must be categorised as "definite", "probable" or "possible". This 
type of data will add another dimension to road safety research, especially once data has been collected for a range of years.

It would be interesting to compare the results of this study with similar modelling for young female drivers, or with the driving population as a whole. It would also be interesting to factor into this analysis some measure of traffic flow on the roads on which the accidents occur. This may help explain the reason for some of the different results obtained for the Great Britain and London only datasets via the speed-flow relationship.

\section{References}

Broughton, J. and Buckle, G., 2005, Monitoring progress towards the 2010 casualty reduction target. TRL Report TRL643.

Broughton, J. and Hill, J. P., 2005, Mobile phone use by drivers, 2000-03. TRL Report TRL634.

Clarke, D.D., Ward, P., Bartle, C., Truman, W., 2006, Young driver accidents in the UK: The influence of age, experience, and time of day, Accident Analysis \& Prevention, 38(5), 871-878.

Clarke, D.D., Ward, Truman, W., 2006, Voluntary risk taking and skill deficits in young driver accidents in the UK, Accident Analysis \& Prevention, 37(5), 523-529.

DETR (Department of the Environment, Transport and the Regions), 2000, Tomorrow's roads: safer for everyone. The Government's road safety strategy and casualty reduction targets for 2010. HMSO, London.

Duncan, C. S., Khattak, A. J., \& Council, F. M.,1998, Applying the ordered probit model to injury severity in truck- passenger car rear-end collisions. Transportation Research Record, 1635, 63-71.

Golias, I. and Karlaftis, M. G., 2002, An international comparative study of self-reported driver behaviour. Transportation Research Part F, 4, 243-256.

Kockelman, K. M. and Kweon, Y.-J., 2002, Driver injury severity: an application of ordered probit models. Accident Analysis and Prevention, 34, 313-321.

Mathijssen, M. P. M., 2005, Drink driving policy and road safety in the Netherlands: a retrospective analysis. Transportation Research Part E, 41, 395-408.

Moller, M., 2004, An explorative study of the relationship between lifestyle and driving behaviour among young drivers, Accident Analysis \& Prevention, 36 (6),1081-1088.

Noland, R. B. and Quddus, M. A., 2003, Medical treatment and traffic fatality reductions in industrialized countries. Accident Analysis and Prevention, 35, 877-883

O’Donnell, C. J., \& Connor, D. H., 1996, Predicting the severity of motor vehicle accident injuries using models of ordered multiple choice. Accident Analysis and Prevention, 28(6), 739- 753. 
Quddus, M. A., Noland, R. B. and Chin, H. C., 2002, An analysis of motorcycle injury and vehicle damage severity using ordered probit models. Journal of Safety Research, 33, 445-462

Tay, R., 2005, The effectiveness of enforcement and publicity campaigns on serious crashes involving young male drivers: Are drink driving and speeding similar? Accident Analysis and Prevention, 37, 922-929.

Transport for London, 2001, London’s Road Safety Plan, London, United Kingdom

Ulleberg, P., 2002, Personality subtypes of young drivers. Relationship to risk-taking preferences, accident involvement, and response to a traffic safety campaign. Transportation Research Part F, 4, 279-297.

Vaez, M. and Laflamme, L., 2005, Impaired driving and motor vehicle crashes among Swedish youth: An investigation into drivers' sociodemographic characteristics. Accident Analysis and Prevention, 37, 605-611.

Ward, H., Shepherd, N., Robertson, S. and Thomas, M., 2005, Night-time accidents, a scoping study. The AA Motoring Trust and Rees Jeffreys Road Fund. Centre for Transport Studies, University College London, UK. 
Table 1: STATS19 variables used in the analysis (* denotes reference case)

\begin{tabular}{|c|c|c|}
\hline Variables & Categories & Coding of variable \\
\hline Time trend & - & Year of accident (assuming that $1991^{*}=1$ to $2003=13$ ) \\
\hline Towing and articulation & $\begin{array}{l}\text { no tow/articulation* } \\
\text { tow/articulation }\end{array}$ & $\begin{array}{l}\text { If accident involved no tow/articulation }=1 \text {, otherwise }=0 \\
\text { If accident involved tow/articulation }=1 \text {, otherwise }=0\end{array}$ \\
\hline Vehicle manoeuvre & $\begin{array}{l}\text { reversing } \\
\text { parked } \\
\text { waiting to move } \\
\text { stopping } \\
\text { u-turn } \\
\text { going ahead* } \\
\text { overtaking } \\
\text { changing lane } \\
\end{array}$ & $\begin{array}{l}\text { If accident involved reversing vehicle }=1 \text {, otherwise }=0 \\
\text { If accident involved parked vehicle }=1 \text {, otherwise }=0 \\
\text { If accident involved vehicle waiting to move }=1 \text {, otherwise }=0 \\
\text { If accident involved stopping vehicle }=1 \text {, otherwise }=0 \\
\text { If accident involved vehicle conducting } u \text {-turn }=1 \text {, otherwise }=0 \\
\text { If accident involved vehicle going ahead }=1 \text {, otherwise }=0 \\
\text { If accident involved overtaking vehicle }=1 \text {, otherwise }=0 \\
\text { If accident involved vehicle changing lane }=1 \text {, otherwise }=0\end{array}$ \\
\hline Vehicle location - road & $\begin{array}{l}\text { leaving main road } \\
\text { entering main road } \\
\text { on the main road* } \\
\text { on minor road }\end{array}$ & $\begin{array}{l}\text { If leaving main road }=1 \text {, otherwise }=0 \\
\text { If entering main road }=1 \text {, otherwise }=0 \\
\text { If on the main road }=1 \text {, otherwise }=0 \\
\text { If on minor road }=1 \text {, otherwise }=0\end{array}$ \\
\hline Skidding and overturning & $\begin{array}{l}\text { no volatile movement* } \\
\text { volatile movement }\end{array}$ & $\begin{array}{l}\text { If no volatile movement }=1 \text {, otherwise }=0 \\
\text { If volatile movement }=1 \text {, otherwise }=0\end{array}$ \\
\hline Hit object off carriageway & $\begin{array}{l}\text { hit none* } \\
\text { hit object }\end{array}$ & $\begin{array}{l}\text { If hit none }=1, \text { otherwise }=0 \\
\text { If hit object }=1, \text { otherwise }=0\end{array}$ \\
\hline Damage & $\begin{array}{l}\text { no damage* } \\
\text { damage }\end{array}$ & $\begin{array}{l}\text { If no damage }=1 \text {, otherwise }=0 \\
\text { If damage }=1 \text {, otherwise }=0\end{array}$ \\
\hline Age of driver & $\begin{array}{l}17-19 \\
20-22 \\
23-25 *\end{array}$ & $\begin{array}{l}\text { If driver } 17-19=1, \text { otherwise }=0 \\
\text { If driver } 20-22=1, \text { otherwise }=0 \\
\text { If driver } 23-25=1, \text { otherwise }=0\end{array}$ \\
\hline Breath test & $\begin{array}{l}\text { negative } \\
\text { postitive } \\
\text { other* }\end{array}$ & $\begin{array}{l}\text { If negative }=1, \text { otherwise }=0 \\
\text { If positive }=1, \text { otherwise }=0 \\
\text { If other }=1, \text { otherwise }=0\end{array}$ \\
\hline Regions & $\begin{array}{l}\text { SW } \\
\text { Scotland } \\
\text { SE } \\
\text { Wales } \\
\text { East } \\
\text { E Midlands } \\
\text { W Midlands } \\
\text { NE } \\
\text { NW } \\
\text { London* } \\
\end{array}$ & $\begin{array}{l}\text { If accident in } \mathrm{SW}=1 \text {, otherwise }=0 \\
\text { If accident in } \mathrm{Scotland}=1 \text {, otherwise }=0 \\
\text { If accident in } \mathrm{SE}=1 \text {, otherwise }=0 \\
\text { If accident in Wales }=1 \text {, otherwise }=0 \\
\text { If accident in East }=1 \text {, otherwise }=0 \\
\text { If accident in } \mathrm{E} \text { Midlands }=1 \text {, otherwise }=0 \\
\text { If accident in W Midlands }=1 \text {, otherwise }=0 \\
\text { If accident in } \mathrm{NE}=1 \text {, otherwise }=0 \\
\text { If accident in } \mathrm{NW}=1 \text {, otherwise }=0 \\
\text { If accident in London }=1 \text {, otherwise }=0\end{array}$ \\
\hline Seasonal effects & $\begin{array}{l}\text { January* } \\
\text { February } \\
\text { March } \\
\text { April } \\
\text { May } \\
\text { June } \\
\text { July } \\
\text { August } \\
\text { September } \\
\text { October } \\
\text { November } \\
\text { December }\end{array}$ & $\begin{array}{l}\text { If accident in January }=1 \text {, otherwise }=0 \\
\text { If accident in February }=1 \text {, otherwise }=0 \\
\text { If accident in March }=1 \text {, otherwise }=0 \\
\text { If accident in April }=1 \text {, otherwise }=0 \\
\text { If accident in May }=1 \text {, otherwise }=0 \\
\text { If accident in June }=1 \text {, otherwise }=0 \\
\text { If accident in July }=1 \text {, otherwise }=0 \\
\text { If accident in August }=1 \text {, otherwise }=0 \\
\text { If accident in September }=1 \text {, otherwise }=0 \\
\text { If accident in October }=1 \text {, otherwise }=0 \\
\text { If accident in November }=1 \text {, otherwise }=0 \\
\text { If accident in December }=1 \text {, otherwise }=0\end{array}$ \\
\hline Day of week effect & $\begin{array}{l}\text { Monday* } \\
\text { Tuesday } \\
\text { Wednesday } \\
\text { Thursday } \\
\text { Friday } \\
\text { Saturday } \\
\text { Sunday } \\
\end{array}$ & $\begin{array}{l}\text { If accident on Monday }=1, \text { otherwise }=0 \\
\text { If accident on Tuesday }=1 \text {, otherwise }=0 \\
\text { If accident on Wednesday }=1 \text {, otherwise }=0 \\
\text { If accident on Thursday }=1 \text {, otherwise }=0 \\
\text { If accident on Friday }=1 \text {, otherwise }=0 \\
\text { If accident on Saturday }=1 \text {, otherwise }=0 \\
\text { If accident on Sunday }=1 \text {, otherwise }=0\end{array}$ \\
\hline Time of day effect & $\begin{array}{l}0000-0659 \\
0700-0959 \\
1000-1559 \\
1600-1859 \\
1900-2359 *\end{array}$ & $\begin{array}{l}\text { If accident between } 0000-0659=1, \text { otherwise }=0 \\
\text { If accident between } 0700-0959=1, \text { otherwise }=0 \\
\text { If accident between } 1000-1559=1, \text { otherwise }=0 \\
\text { If accident between } 1600-1859=1, \text { otherwise }=0 \\
\text { If accident between } 1900-2359=1, \text { otherwise }=0\end{array}$ \\
\hline
\end{tabular}


Table 1 (continued): STATS19 variables used in the analysis (* denotes reference case)

\begin{tabular}{|c|c|c|}
\hline Variables & Categories & Coding of variable \\
\hline Road category & $\begin{array}{l}\mathrm{A}^{*} \\
\mathrm{~A}(\mathrm{M}) \\
\mathrm{B} \\
\mathrm{C} \\
\text { motorway } \\
\text { unclassified }\end{array}$ & $\begin{array}{l}\text { If } \mathrm{A} \text { road }=1, \text { otherwise }=0 \\
\text { If } \mathrm{A}(\mathrm{M}) \mathrm{road}=1, \text { otherwise }=0 \\
\text { If } \mathrm{B} \text { road }=1, \text { otherwise }=0 \\
\text { If } \mathrm{C} \text { road }=1, \text { otherwise }=0 \\
\text { If motorway }=1, \text { otherwise }=0 \\
\text { If unclassified road }=1, \text { otherwise }=0\end{array}$ \\
\hline Road type & $\begin{array}{l}\text { roundabout } \\
\text { one way street } \\
\text { dual carriageway } \\
\text { single carriageway* }\end{array}$ & $\begin{array}{l}\text { If roundabout }=1, \text { otherwise }=0 \\
\text { If one way street }=1, \text { otherwise }=0 \\
\text { If dual carriageway }=1, \text { otherwise }=0 \\
\text { If single carriageway }=1 \text {, otherwise }=0\end{array}$ \\
\hline Speed limit & $\begin{array}{l}=30^{*} \\
40 \\
50 \\
60 \\
70\end{array}$ & $\begin{array}{l}\text { If speed limit is }=30=1 \text {, otherwise }=0 \\
\text { If speed limit is } 40=1 \text {, otherwise }=0 \\
\text { If speed limit is } 50=1 \text {, otherwise }=0 \\
\text { If speed limit is } 60=1 \text {, otherwise }=0 \\
\text { If speed limit is } 70=1 \text {, otherwise }=0\end{array}$ \\
\hline Junction detail & $\begin{array}{l}\text { not at junction or within } 20 \text { metres* } \\
\text { roundabout } \\
\text { mini-roundabout } \\
\text { t, y or staggered junction } \\
\text { slip road } \\
\text { crossroads } \\
\text { multiple junction } \\
\text { private drive or entrance } \\
\text { other junction }\end{array}$ & $\begin{array}{l}\text { If accident not at junction or within } 20 \text { metres }=1 \text {, otherwise }=0 \\
\text { If accident at roundabout }=1 \text {, otherwise }=0 \\
\text { If accident at mini-roundabout }=1 \text {, otherwise }=0 \\
\text { If accident at } t, y \text { or staggered junction }=1 \text {, otherwise }=0 \\
\text { If accident on slip road }=1 \text {, otherwise }=0 \\
\text { If accident at crossroads }=1 \text {, otherwise }=0 \\
\text { If accident at multiple junction }=1, \text { otherwise }=0 \\
\text { If accident at private drive or entrance }=1 \text {, otherwise }=0 \\
\text { If accident at other junction }=1 \text {, otherwise }=0\end{array}$ \\
\hline Light conditions & $\begin{array}{l}\text { daylight* } \\
\text { darkness }\end{array}$ & $\begin{array}{l}\text { If daylight }=1, \text { otherwise }=0 \\
\text { If darkness }=1, \text { otherwise }=0\end{array}$ \\
\hline Weather conditions & $\begin{array}{l}\text { fine no high winds* } \\
\text { raining no high winds } \\
\text { snowing no high winds } \\
\text { fine + high winds } \\
\text { raining + high winds } \\
\text { snowing + high winds } \\
\text { fog or mist } \\
\text { other }\end{array}$ & $\begin{array}{l}\text { If fine no high winds }=1 \text {, otherwise }=0 \\
\text { If raining no high winds }=1 \text {, otherwise }=0 \\
\text { If snowing no high winds }=1 \text {, otherwise }=0 \\
\text { If fine }+ \text { high winds }=1 \text {, otherwise }=0 \\
\text { If raining }+ \text { high winds }=1 \text {, otherwise }=0 \\
\text { If snowing }+ \text { high winds }=1 \text {, otherwise }=0 \\
\text { If fog or mist }=1 \text {, otherwise }=0 \\
\text { If other }=1 \text {, otherwise }=0\end{array}$ \\
\hline Road surface conditions & $\begin{array}{l}\text { dry* } \\
\text { wet or damp } \\
\text { snow } \\
\text { frost or ice } \\
\text { flood over } 3 \mathrm{~cm} \text { deep } \\
\text { mud (from 1999) } \\
\text { oil or diesel (from 1999) }\end{array}$ & $\begin{array}{l}\text { If dry }=1, \text { otherwise }=0 \\
\text { If wet or damp }=1, \text { otherwise }=0 \\
\text { If snow }=1, \text { otherwise }=0 \\
\text { If frost or ice }=1, \text { otherwise }=0 \\
\text { If flood over } 3 \mathrm{~cm} \text { deep }=1, \text { otherwise }=0 \\
\text { If mud }=1, \text { otherwise }=0 \\
\text { If oil or diesel }=1, \text { otherwise }=0\end{array}$ \\
\hline Carriageway hazards & $\begin{array}{l}\text { none* } \\
\text { object on road } \\
\text { previous accident } \\
\text { animal on road }\end{array}$ & $\begin{array}{l}\text { If none }=1, \text { otherwise }=0 \\
\text { If object on road }=1, \text { otherwise }=0 \\
\text { If previous accident }=1, \text { otherwise }=0 \\
\text { If animal on road }=1, \text { otherwise }=0\end{array}$ \\
\hline
\end{tabular}


Table 2: Ordered probit estimates - injury severity of accidents involving young male drivers (Great Britain and London)

\begin{tabular}{|c|c|c|c|c|c|}
\hline \multirow{2}{*}{ Variables } & \multirow{2}{*}{ Categories } & \multicolumn{2}{|c|}{ Great Britain } & \multicolumn{2}{|c|}{ London } \\
\hline & & Coeff & $t$-stat & Coeff & $t$-stat \\
\hline Time trend & - & -0.0204 & -30.51 & -0.0143 & -7.32 \\
\hline \multirow[t]{2}{*}{ Towing and articulation } & no tow/articulation (Reference) & - & & - & \\
\hline & tow/articulation & 0.0315 & 0.79 & -0.0414 & -0.12 \\
\hline \multirow[t]{8}{*}{ Vehicle manoeuvre } & reversing & -0.1704 & -7.50 & -0.1167 & -2.03 \\
\hline & parked & -0.0633 & -4.00 & 0.0534 & 1.39 \\
\hline & waiting to move & -0.5138 & -49.33 & -0.4601 & -18.60 \\
\hline & stopping & -0.4786 & -37.42 & -0.3376 & -8.66 \\
\hline & u-turn & -0.1560 & -6.51 & -0.1624 & -3.57 \\
\hline & going ahead (Reference) & - & - & - & \\
\hline & overtaking & 0.0943 & 11.05 & 0.0521 & 1.54 \\
\hline & changing lane & -0.0503 & -2.62 & -0.1527 & -3.40 \\
\hline \multirow[t]{4}{*}{ Vehicle location - road } & leaving main road & -0.0247 & -2.64 & -0.0481 & -2.11 \\
\hline & entering main road & -0.0930 & -11.36 & -0.0842 & -4.18 \\
\hline & on the main road (Reference) & - & & - & \\
\hline & on minor road & -0.0768 & -9.17 & -0.0475 & -1.50 \\
\hline \multirow[t]{2}{*}{ Skidding and overturning } & no volatile movement (Reference) & - & & - & \\
\hline & volatile movement & 0.0682 & 14.04 & 0.2250 & 11.06 \\
\hline \multirow[t]{2}{*}{ Hit object off carriageway } & hit none (Reference) & - & - & - & 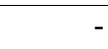 \\
\hline & hit object & 0.1212 & 21.24 & 0.2311 & 11.48 \\
\hline \multirow[t]{2}{*}{ Damage to vehicle } & no damage (Reference) & - & - & - & \\
\hline & damage & -0.0605 & -8.61 & 0.0189 & 1.15 \\
\hline \multirow[t]{3}{*}{ Age of driver } & $17-19$ & -0.0247 & -4.86 & 0.0275 & 1.94 \\
\hline & $20-22$ & 0.0028 & 0.56 & 0.0285 & 2.17 \\
\hline & 23-25 (Reference) & - & 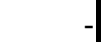 & - & \\
\hline \multirow{3}{*}{ Breath test } & negative & 0.0489 & 11.23 & 0.1202 & 9.62 \\
\hline & postitive & 0.0275 & 2.61 & 0.1015 & 2.89 \\
\hline & other (Reference) & - & - & - & \\
\hline \begin{tabular}{|l} 
Police force \\
\end{tabular} & SW & -0.1141 & -11.92 & - & \\
\hline \multirow{9}{*}{ (Reginal effects) } & Scotland & 0.1283 & 13.78 & - & \\
\hline & $\mathrm{SE}$ & -0.1064 & -12.66 & - & \\
\hline & Wales & -0.1245 & -11.28 & - & \\
\hline & East & -0.0032 & -0.36 & - & \\
\hline & E Midlands & -0.0082 & -0.87 & - & - \\
\hline & W Midlands & 0.0101 & 1.16 & - & \\
\hline & $\mathrm{NE}$ & -0.0437 & -5.34 & - & \\
\hline & NW & -0.1259 & -15.32 & - & \\
\hline & London (Reference) & - & - & - & \\
\hline \multirow[t]{12}{*}{ Seasonal effects } & January (Reference) & - & - & - & \\
\hline & February & -0.0343 & -3.33 & -0.0475 & -1.70 \\
\hline & March & -0.0046 & -0.45 & -0.0304 & -1.11 \\
\hline & April & -0.0011 & -0.10 & -0.0202 & -0.73 \\
\hline & May & 0.0049 & 0.47 & 0.0087 & 0.31 \\
\hline & June & -0.0022 & -0.21 & -0.0169 & -0.61 \\
\hline & July & -0.0117 & -1.12 & -0.0031 & -0.11 \\
\hline & August & 0.0068 & 0.67 & -0.0374 & -1.33 \\
\hline & September & -0.0109 & -1.07 & -0.0386 & -1.41 \\
\hline & October & -0.0157 & -1.59 & -0.0044 & -0.16 \\
\hline & November & -0.0195 & -2.03 & -0.0458 & -1.71 \\
\hline & December & -0.0144 & -1.49 & -0.0738 & -2.74 \\
\hline \multirow[t]{7}{*}{ Day of week effect } & Monday (Reference) & - & 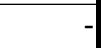 & - & \\
\hline & Tuesday & -0.0098 & -1.21 & -0.0073 & -0.34 \\
\hline & Wednesday & -0.0031 & -0.39 & -0.0095 & -0.44 \\
\hline & Thursday & 0.0045 & 0.57 & -0.0042 & -0.19 \\
\hline & Friday & 0.0255 & 3.41 & 0.0376 & 1.80 \\
\hline & Saturday & 0.0571 & 7.65 & 0.0657 & 3.17 \\
\hline & Sunday & 0.0467 & 6.02 & 0.0370 & 1.73 \\
\hline
\end{tabular}


Table 2 (continued): Ordered probit estimates - injury severity of accidents involving young male drivers (Great Britain and London)

\begin{tabular}{|c|c|c|c|c|c|}
\hline \multirow{2}{*}{ Variables } & \multirow{2}{*}{ Categories } & \multicolumn{2}{|c|}{ Great Britain } & \multicolumn{2}{|c|}{ London } \\
\hline & & Coeff & $t$-stat & Coeff & $t$-stat \\
\hline \multirow[t]{5}{*}{ Hour of accident } & 0000-0659 & 0.0902 & 12.49 & 0.0663 & 3.44 \\
\hline & 0700-0959 & -0.1071 & -12.21 & -0.0465 & -1.83 \\
\hline & $1000-1559$ & -0.1044 & -14.15 & -0.0539 & -2.47 \\
\hline & $1600-1859$ & -0.0719 & -11.23 & -0.0669 & -3.53 \\
\hline & 1900-2359 (Reference) & - & - & - & - \\
\hline \multirow[t]{6}{*}{ First road class } & A (Reference) & - & - & - & - \\
\hline & $\mathrm{A}(\mathrm{M})$ & -0.2964 & -5.82 & -0.2755 & -2.13 \\
\hline & $\mathrm{B}$ & -0.0161 & -2.55 & 0.0148 & 0.75 \\
\hline & $\mathrm{C}$ & -0.0390 & -5.21 & 0.0004 & 0.02 \\
\hline & motorway & -0.1883 & -12.19 & -0.1254 & -2.03 \\
\hline & unclassified & -0.0755 & -13.81 & -0.0519 & -3.22 \\
\hline \multirow[t]{4}{*}{ Road type } & roundabout & -0.1808 & -9.71 & -0.0639 & -1.15 \\
\hline & one way street & -0.0880 & -6.15 & -0.0257 & -0.85 \\
\hline & dual carriageway & -0.0782 & -9.92 & -0.0058 & -0.31 \\
\hline & single carriageway (Reference) & - & - & - & - \\
\hline \multirow[t]{5}{*}{ Speed limit } & $? 30$ (Reference) & - & - & - & - \\
\hline & 40 & 0.1363 & 17.50 & 0.1252 & 5.46 \\
\hline & 50 & 0.1839 & 11.35 & 0.0973 & 2.34 \\
\hline & 60 & 0.2690 & 48.63 & 0.1832 & 4.33 \\
\hline & 70 & 0.2256 & 17.77 & 0.0730 & 1.38 \\
\hline \multirow[t]{9}{*}{ Junction detail } & not at junction or within 20 metres (Reference) & - & & - & - \\
\hline & roundabout & -0.3649 & -22.04 & -0.3082 & -6.27 \\
\hline & mini-roundabout & -0.2435 & -7.80 & -0.1700 & -2.88 \\
\hline & $\mathrm{t}, \mathrm{y}$ or staggered junction & -0.1415 & -26.75 & -0.0874 & -6.01 \\
\hline & slip road & -0.1971 & -11.12 & -0.1193 & -2.13 \\
\hline & crossroads & -0.1638 & -21.79 & -0.0841 & -4.75 \\
\hline & multiple junction & -0.1747 & -16.25 & -0.1562 & -3.77 \\
\hline & private drive or entrance & -0.2382 & -21.78 & -0.1524 & -4.78 \\
\hline & other junction & -0.2245 & -14.45 & -0.1797 & -3.12 \\
\hline \multirow[t]{2}{*}{ Light conditions } & daylight (Reference) & - & & - & - \\
\hline & darkness & 0.1144 & 17.81 & 0.0786 & 4.10 \\
\hline \multirow[t]{8}{*}{ Weather conditions } & fine no high winds (Reference) & - & & - & - \\
\hline & raining no high winds & -0.1201 & -17.26 & -0.0911 & -4.15 \\
\hline & snowing no high winds & -0.1047 & -3.00 & 0.0728 & 0.59 \\
\hline & fine + high winds & -0.0058 & -0.36 & 0.1038 & 1.79 \\
\hline & raining + high winds & -0.0564 & -3.41 & 0.0353 & 0.49 \\
\hline & snowing + high winds & -0.0877 & -1.42 & -0.0321 & -0.11 \\
\hline & fog or mist & -0.0047 & -0.25 & -0.1262 & -1.39 \\
\hline & other & -0.0861 & -5.91 & 0.0436 & 0.78 \\
\hline \multirow[t]{7}{*}{ Road surface conditions } & dry (Reference) & - & - & - & - \\
\hline & wet or damp & -0.0274 & -4.86 & 0.0195 & 1.08 \\
\hline & snow & -0.2510 & -6.47 & -0.3334 & -2.05 \\
\hline & frost or ice & -0.2693 & -17.15 & -0.1355 & -2.36 \\
\hline & flood over $3 \mathrm{~cm}$ deep & -0.1804 & -3.63 & -0.6940 & -2.70 \\
\hline & mud (from 1999) & -0.3339 & -2.88 & -5.6272 & 0.00 \\
\hline & oil or diesel (from 1999) & 0.0351 & 0.35 & 0.2476 & 0.61 \\
\hline \multirow[t]{4}{*}{ Carriageway hazards } & none (Reference) & - & & - & - \\
\hline & object on road & -0.0824 & -4.52 & -0.2423 & -2.52 \\
\hline & previous accident & 0.1807 & 5.38 & 0.1478 & 1.08 \\
\hline & animal on road & -0.2675 & -13.50 & -0.4370 & -3.60 \\
\hline \multicolumn{6}{|l|}{ Summary statistics } \\
\hline \multicolumn{6}{|c|}{ Ancillary parameters } \\
\hline cut-point1 (k1) & & 0.6527 & & 0.8999 & \\
\hline cut-point 2 (k2) & & 1.9130 & & 2.3716 & \\
\hline Log-likelihood at & nvergence & $-267,706.85$ & & -33665.05 & \\
\hline Observations & & 549,178 & & 73,253 & \\
\hline
\end{tabular}


Table 3: Injury severity probabilities for accidents involving young male drivers, Great Britain

\begin{tabular}{|c|c|c|c|c|c|c|c|}
\hline \multirow[t]{2}{*}{ Variables } & \multirow[t]{2}{*}{ Categories } & \multicolumn{3}{|c|}{ Estimated probability } & \multicolumn{3}{|c|}{$\begin{array}{l}\text { Percent change relative to } \\
\text { reference case }(\%)\end{array}$} \\
\hline & & Slight & Serious & Fatal & Slight & Serious & Fatal \\
\hline- & Reference case & 0.7496 & 0.2238 & 0.0266 & - & - & \\
\hline Time trend & 2003 & 0.8207 & 0.1646 & 0.0147 & $9 \%$ & $-26 \%$ & $-45 \%$ \\
\hline Towing and articulation & $\begin{array}{l}\text { no tow/articulation (Reference) } \\
\text { tow/articulation }\end{array}$ & $\begin{array}{r}- \\
0.7394\end{array}$ & 0.2320 & 0.0286 & $\begin{array}{r}- \\
-1 \%\end{array}$ & - & $8 \%$ \\
\hline Vehicle manoeuvre & $\begin{array}{l}\text { reversing } \\
\text { parked } \\
\text { waiting to move } \\
\text { stopping } \\
\text { u-turn } \\
\text { going ahead (Reference) } \\
\text { overtaking } \\
\text { changing lane } \\
\end{array}$ & $\begin{array}{r}0.8005 \\
0.7693 \\
0.8824 \\
0.8753 \\
0.7965 \\
- \\
0.7187 \\
0.7653 \\
\end{array}$ & $\begin{array}{r}0.1818 \\
0.2078 \\
0.1104 \\
0.1168 \\
0.1852 \\
- \\
0.2484 \\
0.2111 \\
\end{array}$ & $\begin{array}{r}0.0177 \\
0.0229 \\
0.0072 \\
0.0079 \\
0.0183 \\
- \\
0.0330 \\
0.0236 \\
\end{array}$ & $\begin{array}{r}7 \% \\
3 \% \\
18 \% \\
17 \% \\
6 \% \\
- \\
-4 \% \\
2 \% \\
\end{array}$ & $\begin{array}{r}-19 \% \\
-7 \% \\
-51 \% \\
-48 \% \\
-17 \% \\
- \\
11 \% \\
-6 \% \\
\end{array}$ & $\begin{array}{r}-33 \% \\
-14 \% \\
-73 \% \\
-70 \% \\
-31 \% \\
- \\
24 \% \\
-11 \% \\
\end{array}$ \\
\hline Vehicle location - road & $\begin{array}{l}\text { leaving main road } \\
\text { entering main road } \\
\text { on the main road (Reference) } \\
\text { on minor road }\end{array}$ & $\begin{array}{r}0.7574 \\
0.7782 \\
- \\
0.7734 \\
\end{array}$ & $\begin{array}{r}0.2175 \\
0.2004 \\
- \\
0.2044 \\
\end{array}$ & $\begin{array}{r}0.0251 \\
0.0214 \\
- \\
0.0222 \\
\end{array}$ & $\begin{array}{r}1 \% \\
4 \% \\
- \\
3 \% \\
\end{array}$ & $\begin{array}{r}-3 \% \\
-10 \% \\
- \\
-9 \% \\
\end{array}$ & $\begin{array}{r}-6 \% \\
-20 \% \\
- \\
-17 \% \\
\end{array}$ \\
\hline Skidding and overturning & $\begin{array}{l}\text { no volatile movement (Reference) } \\
\text { volatile movement }\end{array}$ & $\begin{array}{r}- \\
0.7274\end{array}$ & $\begin{array}{r}- \\
0.2415 \\
\end{array}$ & 0.0311 & $\begin{array}{r}- \\
-3 \% \\
\end{array}$ & - & $17 \%$ \\
\hline Hit object off carriageway & $\begin{array}{l}\text { hit none (Reference) } \\
\text { hit object }\end{array}$ & $\begin{array}{r}- \\
0.7095\end{array}$ & $\begin{array}{r}- \\
0.2555 \\
\end{array}$ & 0.0350 & $\begin{array}{r}- \\
-5 \% \\
\end{array}$ & $\begin{array}{r}- \\
14 \% \\
\end{array}$ & $32 \%$ \\
\hline Damage to vehicle & $\begin{array}{l}\text { no damage (Reference) } \\
\text { damage }\end{array}$ & $\begin{array}{r}- \\
0.7684 \\
\end{array}$ & $\begin{array}{r}- \\
0.2085 \\
\end{array}$ & $\begin{array}{r}- \\
0.0231 \\
\end{array}$ & $\begin{array}{r}- \\
\% \\
\end{array}$ & $\begin{array}{r}- \\
-7 \% \\
\end{array}$ & $-13 \%$ \\
\hline Age of driver & $\begin{array}{l}17-19 \\
20-22 \\
23-25 \text { (Reference) } \\
\end{array}$ & $\begin{array}{r}0.7574 \\
0.7487 \\
- \\
\end{array}$ & $\begin{array}{r}0.2175 \\
0.2245 \\
-\end{array}$ & $\begin{array}{r}0.0251 \\
0.0268 \\
- \\
\end{array}$ & $\begin{array}{r}1 \% \\
0 \% \\
- \\
\end{array}$ & $\begin{array}{r}-3 \% \\
0 \% \\
- \\
\end{array}$ & $\begin{aligned}-6 \% \\
1 \%\end{aligned}$ \\
\hline Breath test & $\begin{array}{l}\text { negative } \\
\text { postitive } \\
\text { other (Reference) }\end{array}$ & $\begin{array}{r}0.7338 \\
0.7408 \\
-\end{array}$ & $\begin{array}{r}0.2365 \\
0.2309 \\
-\end{array}$ & $\begin{array}{l}0.0298 \\
0.0283\end{array}$ & $\begin{array}{r}-2 \% \\
-1 \% \\
-\end{array}$ & $\begin{array}{r}6 \% \\
3 \% \\
-\end{array}$ & $\begin{array}{r}12 \% \\
7 \%\end{array}$ \\
\hline Police force & $\begin{array}{l}\text { SW } \\
\text { Scotland } \\
\text { SE } \\
\text { Wales } \\
\text { East } \\
\text { E Midlands } \\
\text { W Midlands } \\
\text { NE } \\
\text { NW } \\
\text { London (Reference) } \\
\end{array}$ & $\begin{array}{r}0.7844 \\
0.7071 \\
0.7822 \\
0.7875 \\
0.7506 \\
0.7522 \\
0.7464 \\
0.7633 \\
0.7879 \\
-\end{array}$ & $\begin{array}{r}0.1953 \\
0.2574 \\
0.1971 \\
0.1927 \\
0.2230 \\
0.2217 \\
0.2264 \\
0.2127 \\
0.1924 \\
\end{array}$ & $\begin{array}{l}0.0203 \\
0.0355 \\
0.0207 \\
0.0198 \\
0.0264 \\
0.0261 \\
0.0272 \\
0.0240 \\
0.0197\end{array}$ & $\begin{array}{r}5 \% \\
-6 \% \\
4 \% \\
5 \% \\
0 \% \\
0 \% \\
0 \% \\
2 \% \\
5 \% \\
- \\
\end{array}$ & $\begin{array}{r}-13 \% \\
15 \% \\
-12 \% \\
-14 \% \\
0 \% \\
-1 \% \\
1 \% \\
-5 \% \\
-14 \% \\
\end{array}$ & $\begin{array}{r}-24 \% \\
34 \% \\
-22 \% \\
-26 \% \\
-1 \% \\
-2 \% \\
2 \% \\
-10 \% \\
-26 \%\end{array}$ \\
\hline Seasonal effects & $\begin{array}{l}\text { January (Reference) } \\
\text { February } \\
\text { March } \\
\text { April } \\
\text { May } \\
\text { June } \\
\text { July } \\
\text { August } \\
\text { September } \\
\text { October } \\
\text { November } \\
\text { December } \\
\end{array}$ & $\begin{array}{r}- \\
0.7603 \\
0.7510 \\
0.7499 \\
0.7480 \\
0.7503 \\
0.7533 \\
0.7474 \\
0.7530 \\
0.7545 \\
0.7558 \\
0.7541 \\
\end{array}$ & $\begin{array}{l}- \\
0.2151 \\
0.2227 \\
0.2236 \\
0.2251 \\
0.2233 \\
0.2208 \\
0.2256 \\
0.2210 \\
0.2198 \\
0.2188 \\
0.2201 \\
\end{array}$ & $\begin{array}{l}- \\
0.0246 \\
0.0263 \\
0.0265 \\
0.0269 \\
0.0265 \\
0.0259 \\
0.0270 \\
0.0259 \\
0.0256 \\
0.0254 \\
0.0257 \\
\end{array}$ & \begin{tabular}{r|}
- \\
$1 \%$ \\
$0 \%$ \\
$0 \%$ \\
$0 \%$ \\
$0 \%$ \\
$0 \%$ \\
$0 \%$ \\
$0 \%$ \\
$1 \%$ \\
$1 \%$ \\
$\%$ \\
\end{tabular} & $\begin{array}{r}- \\
-4 \% \\
-1 \% \\
0 \% \\
1 \% \\
0 \% \\
-1 \% \\
1 \% \\
-1 \% \\
-2 \% \\
-2 \% \\
-2 \% \\
\end{array}$ & \begin{tabular}{r|}
$-8 \%$ \\
$-1 \%$ \\
$0 \%$ \\
$1 \%$ \\
$-1 \%$ \\
$-3 \%$ \\
$2 \%$ \\
$-2 \%$ \\
$-4 \%$ \\
$-4 \%$ \\
$-3 \%$ \\
\end{tabular} \\
\hline Day of week effect & $\begin{array}{l}\text { Monday (Reference) } \\
\text { Tuesday } \\
\text { Wednesday } \\
\text { Thursday } \\
\text { Friday } \\
\text { Saturday } \\
\text { Sunday }\end{array}$ & $\begin{array}{r}- \\
0.7527 \\
0.7506 \\
0.7481 \\
0.7414 \\
0.7311 \\
0.7345 \\
\end{array}$ & $\begin{array}{l}0 \\
0.2213 \\
0.2230 \\
0.2250 \\
0.2304 \\
0.2386 \\
0.2359\end{array}$ & $\begin{array}{l}- \\
0.0260 \\
0.0264 \\
0.0269 \\
0.0282 \\
0.0303 \\
0.0296\end{array}$ & $\begin{array}{r}- \\
0 \% \\
0 \% \\
0 \% \\
-1 \% \\
-2 \% \\
-2 \% \\
\end{array}$ & $\begin{array}{r}- \\
-1 \% \\
0 \% \\
1 \% \\
3 \% \\
7 \% \\
5 \% \\
\end{array}$ & \begin{tabular}{r|}
- \\
$-2 \%$ \\
$-1 \%$ \\
$1 \%$ \\
$6 \%$ \\
$14 \%$ \\
$11 \%$ \\
\end{tabular} \\
\hline
\end{tabular}


Table 3 (continued): Injury severity probabilities for accidents involving young male drivers, Great

\section{Britain}

\begin{tabular}{|c|c|c|c|c|c|c|c|}
\hline \multirow[t]{2}{*}{ Variables } & \multirow[t]{2}{*}{ Categories } & \multicolumn{3}{|c|}{ Estimated probability } & \multicolumn{3}{|c|}{$\begin{array}{l}\text { Percent change relative to } \\
\text { reference case }(\%)\end{array}$} \\
\hline & & Slight & Serious & Fatal & Slight & Serious & Fatal \\
\hline Hour of accident & \begin{tabular}{|l|}
$0000-0659$ \\
$0700-0959$ \\
$1000-1559$ \\
$1600-1859$ \\
$1900-2359$ (Reference) \\
\end{tabular} & $\begin{array}{r}0.7200 \\
0.7824 \\
0.7816 \\
0.7719 \\
-\end{array}$ & $\begin{array}{r}0.2473 \\
0.1970 \\
0.1976 \\
0.2057 \\
-\end{array}$ & $\begin{array}{r}0.0326 \\
0.0206 \\
0.0208 \\
0.0225 \\
-\end{array}$ & $\begin{array}{r}-4 \% \\
4 \% \\
4 \% \\
3 \% \\
- \\
\end{array}$ & $\begin{array}{r}10 \% \\
-12 \% \\
-12 \% \\
-8 \% \\
- \\
\end{array}$ & \begin{tabular}{r|}
$23 \%$ \\
$-22 \%$ \\
$-22 \%$ \\
$-16 \%$
\end{tabular} \\
\hline First road class & \begin{tabular}{|l} 
A (Reference) \\
A(M) \\
B \\
C \\
motorway \\
unclassified \\
\end{tabular} & $\begin{array}{r}- \\
0.8339 \\
0.7547 \\
0.7618 \\
0.8055 \\
0.7730 \\
\end{array}$ & $\begin{array}{l}- \\
0.1532 \\
0.2197 \\
0.2139 \\
0.1776 \\
0.2048 \\
\end{array}$ & $\begin{array}{r}- \\
0.0129 \\
0.0256 \\
0.0243 \\
0.0169 \\
0.0223 \\
\end{array}$ & $\begin{array}{r}- \\
11 \% \\
1 \% \\
2 \% \\
7 \% \\
3 \% \\
\end{array}$ & $\begin{array}{r}- \\
-32 \% \\
-2 \% \\
-4 \% \\
-21 \% \\
-9 \% \\
\end{array}$ & $\begin{array}{r}-52 \% \\
-4 \% \\
-9 \% \\
-36 \% \\
-16 \% \\
\end{array}$ \\
\hline Road type & \begin{tabular}{|l|} 
roundabout \\
one way street \\
dual carriageway \\
single carriageway (Reference) \\
\end{tabular} & $\begin{array}{r}0.8034 \\
0.7767 \\
0.7738 \\
- \\
\end{array}$ & $\begin{array}{r}0.1793 \\
0.2017 \\
0.2041 \\
\end{array}$ & $\begin{array}{r}0.0172 \\
0.0216 \\
0.0221 \\
- \\
\end{array}$ & $\begin{array}{r}7 \% \\
4 \% \\
3 \% \\
- \\
\end{array}$ & $\begin{array}{r}-20 \% \\
-10 \% \\
-9 \% \\
- \\
\end{array}$ & \begin{tabular}{l|}
$-35 \%$ \\
$-19 \%$ \\
$-17 \%$
\end{tabular} \\
\hline Speed limit & $\begin{array}{l}? 30 \text { (Reference) } \\
40 \\
50 \\
60 \\
70\end{array}$ & $\begin{array}{r}- \\
0.7043 \\
0.6877 \\
0.6569 \\
0.6728 \\
\end{array}$ & $\begin{array}{r}- \\
0.2595 \\
0.2722 \\
0.2950 \\
0.2834 \\
\end{array}$ & \begin{tabular}{r|}
- \\
0.0362 \\
0.0401 \\
0.0480 \\
0.0438 \\
\end{tabular} & $\begin{array}{r}- \\
-6 \% \\
-8 \% \\
-12 \% \\
-10 \% \\
\end{array}$ & $\begin{array}{r}- \\
16 \% \\
22 \% \\
32 \% \\
27 \% \\
\end{array}$ & $\begin{array}{l}36 \% \\
51 \% \\
81 \% \\
65 \% \\
\end{array}$ \\
\hline Junction detail & $\begin{array}{l}\text { not at junction or within } 20 \text { metres (Reference) } \\
\text { roundabout } \\
\text { mini-roundabout } \\
\text { t, y or staggered junction } \\
\text { slip road } \\
\text { crossroads } \\
\text { multiple junction } \\
\text { private drive or entrance } \\
\text { other junction }\end{array}$ & $\begin{array}{l}0.8504 \\
0.8203 \\
0.7924 \\
0.8079 \\
0.7987 \\
0.8017 \\
0.8190 \\
0.8153\end{array}$ & $\begin{array}{l}0.1388 \\
0.1649 \\
0.1886 \\
0.1755 \\
0.1833 \\
0.1807 \\
0.1661 \\
0.1692\end{array}$ & $\begin{array}{l}0.0108 \\
0.0147 \\
0.0190 \\
0.0166 \\
0.0180 \\
0.0175 \\
0.0149 \\
0.0155\end{array}$ & $\begin{array}{r}13 \% \\
9 \% \\
6 \% \\
8 \% \\
7 \% \\
7 \% \\
9 \% \\
9 \%\end{array}$ & $\begin{array}{l}-38 \% \\
-26 \% \\
-16 \% \\
-22 \% \\
-18 \% \\
-19 \% \\
-26 \% \\
-24 \%\end{array}$ & $\begin{array}{l}-59 \% \\
-45 \% \\
-29 \% \\
-38 \% \\
-32 \% \\
-34 \% \\
-44 \% \\
-42 \%\end{array}$ \\
\hline Light conditions & $\begin{array}{l}\text { daylight (Reference) } \\
\text { darkness }\end{array}$ & $\begin{array}{r}- \\
0.7119 \\
\end{array}$ & $\begin{array}{r}- \\
0.2537\end{array}$ & $\begin{array}{r}- \\
0.0345 \\
\end{array}$ & $\begin{array}{r}- \\
-5 \% \\
\end{array}$ & $\begin{array}{r}- \\
13 \% \\
\end{array}$ & \\
\hline Weather conditions & $\begin{array}{l}\text { fine no high winds (Reference) } \\
\text { raining no high winds } \\
\text { snowing no high winds } \\
\text { fine + high winds } \\
\text { raining + high winds } \\
\text { snowing + high winds } \\
\text { fog or mist } \\
\text { other } \\
\end{array}$ & $\begin{array}{r}- \\
0.7862 \\
0.7817 \\
0.7514 \\
0.7672 \\
0.7766 \\
0.7511 \\
0.7762 \\
\end{array}$ & $\begin{array}{r}- \\
0.1938 \\
0.1976 \\
0.2223 \\
0.2095 \\
0.2017 \\
0.2226 \\
0.2021 \\
\end{array}$ & $\begin{array}{l}- \\
0.0200 \\
0.0208 \\
0.0262 \\
0.0233 \\
0.0216 \\
0.0263 \\
0.0217 \\
\end{array}$ & $\begin{array}{l}- \\
5 \% \\
4 \% \\
0 \% \\
2 \% \\
4 \% \\
0 \% \\
4 \% \\
\end{array}$ & $\begin{array}{r}- \\
-13 \% \\
-12 \% \\
-1 \% \\
-6 \% \\
-10 \% \\
-1 \% \\
-10 \% \\
\end{array}$ & $\begin{array}{r}-25 \% \\
-22 \% \\
-1 \% \\
-12 \% \\
-19 \% \\
-1 \% \\
-18 \% \\
\end{array}$ \\
\hline Road surface conditions & $\begin{array}{l}\text { dry (Reference) } \\
\text { wet or damp } \\
\text { snow } \\
\text { frost or ice } \\
\text { flood over } 3 \mathrm{~cm} \text { deep } \\
\text { mud (from 1999) } \\
\text { oil or diesel (from 1999) }\end{array}$ & $\begin{array}{r}- \\
0.7582 \\
0.8223 \\
0.8270 \\
0.8033 \\
0.8431 \\
0.7383 \\
\end{array}$ & $\begin{array}{l}0.2168 \\
0.1632 \\
0.1592 \\
0.1794 \\
0.1453 \\
0.2329 \\
\end{array}$ & $\begin{array}{l}0.0250 \\
0.0145 \\
0.0138 \\
0.0173 \\
0.0117 \\
0.0288\end{array}$ & $\begin{array}{r}- \\
1 \% \\
10 \% \\
10 \% \\
7 \% \\
12 \% \\
-2 \% \\
\end{array}$ & $\begin{array}{r}- \\
-3 \% \\
-27 \% \\
-29 \% \\
-20 \% \\
-35 \% \\
4 \% \\
\end{array}$ & $\begin{array}{r}-6 \% \\
-46 \% \\
-48 \% \\
-35 \% \\
-56 \% \\
8 \% \\
\end{array}$ \\
\hline Carriageway hazards & \begin{tabular}{|l|} 
none $($ Reference $)$ \\
object on road \\
previous accident \\
animal on road \\
\end{tabular} & $\begin{array}{r}- \\
0.7751 \\
0.6888 \\
0.8266 \\
\end{array}$ & $\begin{array}{r}- \\
0.2030 \\
0.2714 \\
0.1596 \\
\end{array}$ & $\begin{array}{r}- \\
0.0219 \\
0.0398 \\
0.0139 \\
\end{array}$ & $\begin{array}{r}- \\
3 \% \\
-8 \% \\
10 \% \\
\end{array}$ & $\begin{array}{r}- \\
-9 \% \\
21 \% \\
-29 \% \\
\end{array}$ & $\begin{array}{r}-18 \% \\
50 \% \\
-48 \% \\
\end{array}$ \\
\hline
\end{tabular}


Table 4: Injury severity probabilities for accidents involving young male drivers, London

\begin{tabular}{|c|c|c|c|c|c|c|c|}
\hline \multirow[t]{2}{*}{ Variables } & \multirow[t]{2}{*}{ Categories } & \multicolumn{3}{|c|}{ Estimated probability } & \multicolumn{3}{|c|}{$\begin{array}{l}\text { Percent change relative to } \\
\text { reference case }(\%)\end{array}$} \\
\hline & & Slight & Serious & Fatal & Slight & Serious & Fatal \\
\hline- & Reference case & 0.8197 & 0.1718 & 0.0085 & - & - & \\
\hline Time trend & 2003 & 0.8612 & 0.1336 & 0.0053 & $5 \%$ & $-22 \%$ & $-38 \%$ \\
\hline Towing and articulation & $\begin{array}{l}\text { no tow/articulation (Reference) } \\
\text { tow/articulation }\end{array}$ & $\begin{array}{r}- \\
0.8304 \\
\end{array}$ & 0.1620 & 0.0076 & $\begin{array}{r}- \\
1 \% \\
\end{array}$ & $\begin{array}{r}- \\
-6 \% \\
\end{array}$ & $\begin{array}{r}- \\
-11 \% \\
\end{array}$ \\
\hline Vehicle manoeuvre & $\begin{array}{l}\text { reversing } \\
\text { parked } \\
\text { waiting to move } \\
\text { stopping } \\
\text { u-turn } \\
\text { going ahead (Reference) } \\
\text { overtaking } \\
\text { changing lane } \\
\end{array}$ & $\begin{array}{r}0.8487 \\
0.8053 \\
0.9153 \\
0.8947 \\
0.8592 \\
- \\
0.8057 \\
0.8570 \\
\end{array}$ & $\begin{array}{r}0.1451 \\
0.1849 \\
0.0825 \\
0.1021 \\
0.1354 \\
- \\
0.1845 \\
0.1374 \\
\end{array}$ & $\begin{array}{r}0.0062 \\
0.0098 \\
0.0022 \\
0.0032 \\
0.0054 \\
- \\
0.0098 \\
0.0056 \\
\end{array}$ & $\begin{array}{r}4 \% \\
-2 \% \\
12 \% \\
9 \% \\
5 \% \\
- \\
-2 \% \\
5 \% \\
\end{array}$ & $\begin{array}{r}-16 \% \\
8 \% \\
-52 \% \\
-41 \% \\
-21 \% \\
- \\
7 \% \\
-20 \% \\
\end{array}$ & $\begin{array}{r}-28 \% \\
15 \% \\
-74 \% \\
-62 \% \\
-36 \% \\
- \\
15 \% \\
-35 \% \\
\end{array}$ \\
\hline Vehicle location - road & $\begin{array}{l}\text { leaving main road } \\
\text { entering main road } \\
\text { on the main road (Reference) } \\
\text { on minor road }\end{array}$ & $\begin{array}{r}0.8320 \\
0.8409 \\
- \\
0.8319 \\
\end{array}$ & $\begin{array}{r}0.1605 \\
0.1523 \\
- \\
0.1606 \\
\end{array}$ & $\begin{array}{r}0.0075 \\
0.0068 \\
- \\
0.0075 \\
\end{array}$ & $\begin{array}{r}2 \% \\
3 \% \\
- \\
1 \% \\
\end{array}$ & $\begin{array}{r}-7 \% \\
-11 \% \\
- \\
-7 \% \\
\end{array}$ & $\begin{array}{r}-12 \% \\
-21 \% \\
- \\
-12 \% \\
\end{array}$ \\
\hline Skidding and overturning & $\begin{array}{l}\text { no volatile movement (Reference) } \\
\text { volatile movement }\end{array}$ & 0.7546 & $0.2300^{-}$ & 0.0154 & - & $34 \%$ & $80 \%$ \\
\hline Hit object off carriageway & $\begin{array}{l}\text { hit none (Reference) } \\
\text { hit object }\end{array}$ & $\begin{array}{r}- \\
0.7527 \\
\end{array}$ & $\begin{array}{r}- \\
0.2317 \\
\end{array}$ & $\begin{array}{r}- \\
0.0156 \\
\end{array}$ & - & $35 \%$ & $83 \%$ \\
\hline Damage to vehicle & $\begin{array}{l}\text { no damage (Reference) } \\
\text { damage }\end{array}$ & $\begin{array}{r}- \\
0.8147 \\
\end{array}$ & $\begin{array}{r}- \\
0.1764\end{array}$ & 0.0090 & $\begin{array}{r}- \\
-1 \% \\
\end{array}$ & $\begin{array}{r}- \\
3 \% \\
\end{array}$ & $\begin{array}{r}- \\
5 \% \\
\end{array}$ \\
\hline Age of driver & $\begin{array}{l}17-19 \\
20-22 \\
23-25 \text { (Reference) }\end{array}$ & $\begin{array}{r}0.8124 \\
0.8121 \\
-\end{array}$ & $\begin{array}{r}0.1784 \\
0.1787 \\
-\end{array}$ & $\begin{array}{r}0.0092 \\
0.0092 \\
- \\
\end{array}$ & $\begin{array}{r}-1 \% \\
-1 \% \\
-\end{array}$ & $\begin{array}{r}4 \% \\
4 \% \\
- \\
\end{array}$ & $\begin{array}{r}8 \% \\
8 \% \\
- \\
\end{array}$ \\
\hline Breath test & $\begin{array}{l}\text { negative } \\
\text { postitive } \\
\text { other (Reference) }\end{array}$ & $\begin{array}{r}0.7864 \\
0.7918 \\
-\end{array}$ & $\begin{array}{r}0.2019 \\
0.1970 \\
-\end{array}$ & $\begin{array}{r}0.0117 \\
0.0112 \\
- \\
\end{array}$ & $\begin{array}{r}-4 \% \\
-3 \% \\
- \\
\end{array}$ & $\begin{array}{r}18 \% \\
15 \% \\
-\end{array}$ & $\begin{array}{r}38 \% \\
31 \% \\
-\end{array}$ \\
\hline Seasonal effects & $\begin{array}{l}\text { January (Reference) } \\
\text { February } \\
\text { March } \\
\text { April } \\
\text { May } \\
\text { June } \\
\text { July } \\
\text { August } \\
\text { September } \\
\text { October } \\
\text { November } \\
\text { December } \\
\end{array}$ & $\begin{array}{l}- \\
0.8319 \\
0.8276 \\
0.8249 \\
0.8174 \\
0.8241 \\
0.8205 \\
0.8293 \\
0.8296 \\
0.8208 \\
0.8315 \\
0.8384 \\
\end{array}$ & $\begin{array}{l}- \\
0.1606 \\
0.1646 \\
0.1670 \\
0.1739 \\
0.1678 \\
0.1711 \\
0.1630 \\
0.1627 \\
0.1707 \\
0.1610 \\
0.1546 \\
\end{array}$ & $\begin{array}{l}- \\
0.0075 \\
0.0078 \\
0.0081 \\
0.0087 \\
0.0081 \\
0.0084 \\
0.0077 \\
0.0077 \\
0.0084 \\
0.0075 \\
0.0070 \\
\end{array}$ & $\begin{array}{l}- \\
1 \% \\
1 \% \\
1 \% \\
0 \% \\
1 \% \\
0 \% \\
1 \% \\
1 \% \\
0 \% \\
1 \% \\
2 \% \\
\end{array}$ & $\begin{array}{r}- \\
-6 \% \\
-4 \% \\
-3 \% \\
1 \% \\
-2 \% \\
0 \% \\
-5 \% \\
-5 \% \\
-1 \% \\
-6 \% \\
-10 \% \\
\end{array}$ & $\begin{array}{r}- \\
-12 \% \\
-8 \% \\
-5 \% \\
2 \% \\
-5 \% \\
-1 \% \\
-10 \% \\
-10 \% \\
-1 \% \\
-12 \% \\
-18 \% \\
\end{array}$ \\
\hline Day of week effect & $\begin{array}{l}\text { Monday (Reference) } \\
\text { Tuesday } \\
\text { Wednesday } \\
\text { Thursday } \\
\text { Friday } \\
\text { Saturday } \\
\text { Sunday }\end{array}$ & $\begin{array}{l}- \\
0.8216 \\
0.8222 \\
0.8208 \\
0.8096 \\
0.8019 \\
0.8098\end{array}$ & $\begin{array}{l}- \\
0.1700 \\
0.1695 \\
0.1708 \\
0.1809 \\
0.1879 \\
0.1808\end{array}$ & $\begin{array}{l}- \\
0.0084 \\
0.0083 \\
0.0084 \\
0.0094 \\
0.0102 \\
0.0094\end{array}$ & $\begin{array}{r}- \\
0 \% \\
0 \% \\
0 \% \\
-1 \% \\
-2 \% \\
-1 \%\end{array}$ & $\begin{array}{r}- \\
-1 \% \\
-1 \% \\
-1 \% \\
5 \% \\
9 \% \\
5 \%\end{array}$ & \begin{tabular}{r|}
- \\
$-2 \%$ \\
$-3 \%$ \\
$-1 \%$ \\
$11 \%$ \\
$19 \%$ \\
$11 \%$ \\
\end{tabular} \\
\hline Hour of accident & $\begin{array}{l}0000-0659 \\
0700-0959 \\
1000-1559 \\
1600-1859 \\
1900-2359 \text { (Reference) }\end{array}$ & $\begin{array}{r}0.8017 \\
0.8316 \\
0.8335 \\
0.8367 \\
-\end{array}$ & $\begin{array}{r}0.1881 \\
0.1609 \\
0.1592 \\
0.1562 \\
-\end{array}$ & $\begin{array}{r}0.0102 \\
0.0075 \\
0.0073 \\
0.0071 \\
-\end{array}$ & $\begin{array}{r}-2 \% \\
1 \% \\
2 \% \\
2 \% \\
-\end{array}$ & $\begin{array}{r}9 \% \\
-6 \% \\
-7 \% \\
-9 \% \\
-\end{array}$ & $\begin{array}{r}20 \% \\
-12 \% \\
-14 \% \\
-17 \% \\
-\end{array}$ \\
\hline
\end{tabular}


Table 4 (continued): Injury severity probabilities for accidents involving young male drivers, London

\begin{tabular}{|c|c|c|c|c|c|c|c|}
\hline \multirow[t]{2}{*}{ Variables } & \multirow[t]{2}{*}{ Categories } & \multicolumn{3}{|c|}{ Estimated probability } & \multicolumn{3}{|c|}{ Percent change relative to } \\
\hline & & Slight & Serious & Fatal & Slight & Serious & Fatal \\
\hline First road class & $\begin{array}{l}\text { A (Reference) } \\
\text { A(M) } \\
\text { B } \\
\text { C } \\
\text { motorway } \\
\text { unclassified } \\
\end{array}$ & $\begin{array}{r}- \\
0.8829 \\
0.8158 \\
0.8196 \\
0.8507 \\
0.8330 \\
\end{array}$ & $\begin{array}{l}- \\
0.1132 \\
0.1754 \\
0.1719 \\
0.1433 \\
0.1596 \\
\end{array}$ & $\begin{array}{l}0.0039 \\
0.0089 \\
0.0085 \\
0.0060 \\
0.0074\end{array}$ & $\begin{array}{r}- \\
8 \% \\
0 \% \\
0 \% \\
4 \% \\
2 \% \\
\end{array}$ & $\begin{array}{r}- \\
-34 \% \\
2 \% \\
0 \% \\
-17 \% \\
-7 \% \\
\end{array}$ & $\begin{array}{r}-54 \% \\
4 \% \\
0 \% \\
-29 \% \\
-13 \% \\
\end{array}$ \\
\hline Road type & $\begin{array}{l}\text { roundabout } \\
\text { one way street } \\
\text { dual carriageway } \\
\text { single carriageway (Reference) }\end{array}$ & $\begin{array}{r}0.8360 \\
0.8264 \\
0.8212 \\
- \\
\end{array}$ & $\begin{array}{r}0.1569 \\
0.1657 \\
0.1704 \\
-\end{array}$ & $\begin{array}{l}0.0071 \\
0.0079 \\
0.0084\end{array}$ & $\begin{array}{r}2 \% \\
1 \% \\
0 \% \\
-\end{array}$ & $\begin{array}{r}-9 \% \\
-4 \% \\
-1 \% \\
- \\
\end{array}$ & $\begin{array}{r}-16 \% \\
-7 \% \\
-2 \%\end{array}$ \\
\hline Speed limit & $\begin{array}{l}? 30 \text { (Reference) } \\
40 \\
50 \\
60 \\
70\end{array}$ & $\begin{array}{r}- \\
0.7849 \\
0.7930 \\
0.7676 \\
0.7999 \\
\end{array}$ & $\begin{array}{r}- \\
0.2032 \\
0.1959 \\
0.2186 \\
0.1898 \\
\end{array}$ & \begin{tabular}{r|}
- \\
0.0119 \\
0.0111 \\
0.0138 \\
0.0104
\end{tabular} & $\begin{array}{r}- \\
-4 \% \\
-3 \% \\
-6 \% \\
-2 \% \\
\end{array}$ & $\begin{array}{r}- \\
18 \% \\
14 \% \\
27 \% \\
10 \% \\
\end{array}$ & $\begin{array}{l}40 \% \\
30 \% \\
62 \% \\
22 \%\end{array}$ \\
\hline Junction detail & $\begin{array}{l}\text { not at junction or within } 20 \text { metres } \\
\text { roundabout } \\
\text { mini-roundabout } \\
\text { t, y or staggered junction } \\
\text { slip road } \\
\text { crossroads } \\
\text { multiple junction } \\
\text { private drive or entrance } \\
\text { other junction }\end{array}$ & $\begin{array}{l}0.8892 \\
0.8609 \\
0.8417 \\
0.8493 \\
0.8409 \\
0.8578 \\
0.8569 \\
0.8630\end{array}$ & $\begin{array}{l}0.1073 \\
0.1338 \\
0.1516 \\
0.1446 \\
0.1523 \\
0.1367 \\
0.1375 \\
0.1319\end{array}$ & $\begin{array}{l}0.0035 \\
0.0053 \\
0.0067 \\
0.0061 \\
0.0068 \\
0.0055 \\
0.0056 \\
0.0052\end{array}$ & $\begin{array}{l}- \\
8 \% \\
5 \% \\
3 \% \\
4 \% \\
3 \% \\
5 \% \\
5 \% \\
5 \%\end{array}$ & $\begin{array}{l}-38 \% \\
-22 \% \\
-12 \% \\
-16 \% \\
-11 \% \\
-20 \% \\
-20 \% \\
-23 \% \\
\end{array}$ & $\begin{array}{l}-59 \% \\
-38 \% \\
-21 \% \\
-28 \% \\
-21 \% \\
-35 \% \\
-35 \% \\
-40 \% \\
\end{array}$ \\
\hline Light conditions & $\begin{array}{l}\text { daylight (Reference) } \\
\text { darkness }\end{array}$ & $\begin{array}{r}- \\
0.7983 \\
\end{array}$ & $\begin{array}{r}- \\
0.1912 \\
\end{array}$ & $\begin{array}{r}- \\
0.0105 \\
\end{array}$ & $\begin{array}{r}- \\
-3 \% \\
\end{array}$ & $\begin{array}{r}- \\
11 \% \\
\end{array}$ & \\
\hline Weather conditions & $\begin{array}{l}\text { fine no high winds (Reference) } \\
\text { raining no high winds } \\
\text { snowing no high winds } \\
\text { fine + high winds } \\
\text { raining + high winds } \\
\text { snowing + high winds } \\
\text { fog or mist } \\
\text { other }\end{array}$ & $\begin{array}{r}- \\
0.8426 \\
0.7999 \\
0.7911 \\
0.8103 \\
0.8280 \\
0.8509 \\
0.8080 \\
\end{array}$ & $\begin{array}{r}- \\
0.1508 \\
0.1897 \\
0.1976 \\
0.1804 \\
0.1642 \\
0.1431 \\
0.1824 \\
\end{array}$ & \begin{tabular}{r|}
- \\
0.0066 \\
0.0104 \\
0.0112 \\
0.0094 \\
0.0078 \\
0.0060 \\
0.0096 \\
\end{tabular} & $\begin{array}{r}- \\
3 \% \\
-2 \% \\
-3 \% \\
-1 \% \\
1 \% \\
4 \% \\
-1 \% \\
\end{array}$ & $\begin{array}{r}- \\
-12 \% \\
10 \% \\
15 \% \\
5 \% \\
-4 \% \\
-17 \% \\
6 \% \\
\end{array}$ & $\begin{array}{r}-22 \% \\
22 \% \\
32 \% \\
10 \% \\
-8 \% \\
-30 \% \\
12 \% \\
\end{array}$ \\
\hline Road surface conditions & $\begin{array}{l}\text { dry (Reference) } \\
\text { wet or damp } \\
\text { snow } \\
\text { frost or ice } \\
\text { flood over } 3 \mathrm{~cm} \text { deep } \\
\text { mud (from 1999) } \\
\text { oil or diesel (from 1999) } \\
\end{array}$ & $\begin{array}{l}- \\
0.8145 \\
0.8939 \\
0.8531 \\
0.9461 \\
1.0000 \\
0.7475 \\
\end{array}$ & $\begin{array}{l}- \\
0.1765 \\
0.1028 \\
0.1411 \\
0.0529 \\
0.0000 \\
0.2363 \\
\end{array}$ & $\begin{array}{l}- \\
0.0090 \\
0.0033 \\
0.0058 \\
0.0010 \\
0.0000 \\
0.0162 \\
\end{array}$ & $\begin{array}{r}- \\
-1 \% \\
9 \% \\
4 \% \\
15 \% \\
22 \% \\
-9 \% \\
\end{array}$ & $\begin{array}{r}- \\
3 \% \\
-40 \% \\
-18 \% \\
-69 \% \\
-100 \% \\
38 \% \\
\end{array}$ & $\begin{array}{r}- \\
5 \% \\
-62 \% \\
-31 \% \\
-88 \% \\
-100 \% \\
91 \% \\
\end{array}$ \\
\hline Carriageway hazards & $\begin{array}{l}\text { none (Reference) } \\
\text { object on road } \\
\text { previous accident } \\
\text { animal on road }\end{array}$ & $\begin{array}{r}- \\
0.8762 \\
0.7783 \\
0.9117\end{array}$ & $\begin{array}{r}- \\
0.1195 \\
0.2091 \\
0.0859\end{array}$ & $\begin{array}{l}0.0043 \\
0.0126 \\
0.0024\end{array}$ & $\begin{array}{r}- \\
7 \% \\
-5 \% \\
11 \% \\
\end{array}$ & $\begin{array}{r}- \\
-30 \% \\
22 \% \\
-50 \%\end{array}$ & $\begin{array}{r}-50 \% \\
48 \% \\
-72 \% \\
\end{array}$ \\
\hline
\end{tabular}


Table 5: Key characteristics most likely to lead to injuries

\begin{tabular}{|c|c|}
\hline \multicolumn{2}{|c|}{ Fatal and serious injuries } \\
\hline Great Britain & London only \\
\hline Between 0000-0659 & Between 0000-0659 \\
\hline In darkness & In darkness \\
\hline Fine no high winds & In fine weather with high winds \\
\hline $\begin{array}{l}\text { On a road with speed limit of } 60 \mathrm{mph} \text {, most likely a single } \\
\text { carriageway and/or A road }\end{array}$ & $\begin{array}{l}\text { On a road with speed limit of } 60 \mathrm{mph} \text {, most likely a single } \\
\text { carriageway and/or B road }\end{array}$ \\
\hline $\begin{array}{l}\text { Towards the end of the week (Friday-Sunday), particularly } \\
\text { on a Saturday (includes early morning Saturday after a } \\
\text { Friday night) }\end{array}$ & $\begin{array}{l}\text { Towards the end of the week (Friday-Sunday), particularly } \\
\text { on a Saturday (includes early morning Saturday after a } \\
\text { Friday night) }\end{array}$ \\
\hline On a main road, not at a junction, overtaking & $\begin{array}{l}\text { On a main road, not at a junction, either parked or } \\
\text { overtaking }\end{array}$ \\
\hline $\begin{array}{l}\text { When vehicle has skidded, the car has hit an object off the } \\
\text { carriageway, but damage has not been caused }\end{array}$ & $\begin{array}{l}\text { When vehicle has skidded, the car has hit an object off the } \\
\text { carriageway and damage has been caused }\end{array}$ \\
\hline Passing the site of a previous accident & Passing the site of a previous accident \\
\hline \multicolumn{2}{|c|}{ Slight injuries } \\
\hline Great Britain & London only \\
\hline Between 1000-1859 & Between 1000-1859 \\
\hline In daylight & In daylight \\
\hline In rain but no high wi & In fog or mist \\
\hline $\begin{array}{l}\text { On a road with speed limit of } 30 \mathrm{mph} \text { or less, most likely at } \\
\text { a roundabout and } / \text { or } \mathrm{A}(\mathrm{M}) \text { road }\end{array}$ & $\begin{array}{l}\text { On a road with a speed limit of } 30 \mathrm{mph} \text { or less, most likely } \\
\text { at a roundabout and/or } \mathrm{A}(\mathrm{M}) \mathrm{road}\end{array}$ \\
\hline Towards the beginning of the week (Monday-Thursday) & Towards the beginning of the week (Monday-Thursday) \\
\hline Entering a main road, at a roundabout, waiting to move & Entering a main road, at a roundabout, waiting to move \\
\hline $\begin{array}{l}\text { When vehicle has not skidded, the car has not hit an object } \\
\text { off the carriageway, but damage has been caused }\end{array}$ & $\begin{array}{l}\text { When the vehicle has not skidded, the car has not hit an } \\
\text { object off the carriageway and no damage has been } \\
\text { caused }\end{array}$ \\
\hline When there is an animal in the carriageway & When there is an animal in the carriageway \\
\hline
\end{tabular}

